\title{
Peran Wali Murid Terhadap Pembentukan Kedisiplinan Siswa di SD Negeri 10 Banda Aceh
}

\author{
Putry Julia $^{1}$, Danil Juliansyah ${ }^{2}$ \\ ${ }^{1}$ Dosen Fakultas Keguruan dan Ilmu Pendidikan Universitas Serambi Mekkah \\ ${ }^{2}$ Alumni Fakultas Keguruan dan Ilmu Pendidikan Universitas Serambi Mekkah \\ Email.putryjulia@serambimekkah.ac.id
}

\begin{abstract}
Abstrak
Penelitian ini bertujuan untuk mengetahui peran wali murid terhadap pembentukan kedisiplinan pada siswa, untuk mendeskripsikan kendala yang dihadapi wali murid dalam pembentukan kedisiplinan dan untuk menggambarkan upaya yang dilakukan oleh wali murid dalam menghadapi kendala pembentukan pembentukan kedisiplinan pada siswa di SD Negeri 10 Banda Aceh. Metode penelitian ini menggunakan pendekatan kualitatif dan jenis penelitian yang dipilih adalah penelitian deskriptif. Subjek penelitian ini adalah 30 orang wali murid, 30 orang siswa dan 3 orang komite sekolah. Data dikumpulkan melalui wawancara dan angket dengan menggunakan 30 butir pertanyaan. Instrumen disusun dengan menggunakan skala likert. Data dianalisis dengan menggunakan teknik statistik deskriptif. Hasil penelitian menunjukkan bahwa wali murid berperan aktif dalam pembentukan kedisiplinan siswa. Wali murid menolong anak saat menghadapi kesulitan dalam mengerjakan tugas, menyelesaikan hal-hal yang sulit, mengatur waktu anak dalam belajar, memimbing tingkah laku anak dan mengajarkan pentingnya belajar secara disiplin. Kendala yang dihadapi wali murid dalam pembentukan kedisiplinan pada anak dikarenakan beberapa faktor diantaranya keterbatasan waktu yang dimiliki wali murid, khususnya yang bekerja. Upaya yang dilakukan oleh wali murid dalam mengatasi kendala pembentukan kedisiplinan siswa adalah dengan memberikan bimbingan terhadap anak secara berkelanjutan dan memberikan hadiah dan pujian terhadap siswa yang telah mampu menerapkan kedisiplinan.
\end{abstract}

\section{Kata Kunci : Peran Wali Murid, Pembentukan Kedisiplinan}

\section{PENDAHULUAN}

Menurut Rahmat (2008:21) dari sisi psikologis, disiplin adalah kemampuan mengendalikan perilaku yang berasal dari dalam diri seseorang sesuai dengan hal-hal yang telah di atur dari luar atau norma yang sudah ada. Dengan kata lain, disiplin dari segi psikologis merupakan perilaku seseorang yang muncul dan mampu menyesuaikan diri dengan aturan yang telah ditetapkan.

Disiplin merupakan kunci sukses bagi kegiatan belajar siswa di sekolah, karena dengan disiplin maka setiap siswa akan menciptakan rasa nyaman serta aman belajar bagi dirinya sendiri, sekaligus bagi siswa lain yang berada dilingkungan sekolah. Disiplin yang dikehendaki disini adalah disiplin yang muncul karena kesadaran bukan karena paksaan. Disiplin yang muncul karena kesadaran disebabkan karena siswa telah menyadari bahwa hanya dengan disiplin akan didapatkan kesuksesan dalam segala hal, dengan disiplin akan dapat menghilangkan kekecewaan orang lain, dan dengan disiplinlah orang lain dapat mengaguminya. Disiplin tentu tidak akan muncul begitu saja pada diri siswa tanpa didasari dengan penegakan peraturan yang efektif oleh pihak 
guru di sekolah, melalui penegakan peraturan yang berupa tata tertib sekolah secara baik dan benar.

Hasil observasi awal di SD Negeri 10 Banda Aceh menunjukkan bahwa siswa di sekolah tersebut belum memiliki kesadaran yang tinggi akan pentingnya kedisiplinan dalam proses belajar di sekolah. Hal ini dapat terlihat dari keterlambatan siswa saat hadir ke sekolah, siswa tidak menyelesaikan PR yang diberikan oleh guru, siswa tidak memakai atribut sekolah seperti dasi, topi dan tali pinggang. Hal ini dikarenakan siswa di tingkat SD belum menyadari peranan kedisiplinan sebagai faktor pendukung untuk mencapai keberhasilan di sekolah.

Keluarga merupakan salah satu unsur penting dalam pendidikan. Sunarto dan Hartono (2008:193) menyatakan bahwa "keluarga merupakan lingkungan pendidikan yang pertama dan utama bagi anak-anak dan remaja. Pendidikan keluarga lebih menekankan pada aspek moral atau pembentukan kepribadian daripada pendidikan untuk menguasai ilmu pengetahuan”. Orang tua adalah komponen keluarga yang terdiri dari ayah dan ibu, dan merupakan hasil dari sebuah ikatan perkawinan yang sah yang dapat membentuk sebuah keluarga. Orang tua memiliki tanggung jawab untuk mendidik, mengasuh dan membimbing anak-anaknya untuk mencapai tahapan tertentu yang menghantarkan anak untuk siap dalam kehidupan bermasyarakat. Sedangkan pengertian orang tua di atas, tidak terlepas dari pengertian keluarga, karena orang tua merupakan bagian keluarga besar yang sebagian besar telah tergantikan oleh keluarga inti yang terdiri dari ayah, ibu dan anak-anak.

Berdasarkan uraian latar belakang di atas, maka penulis tertarik untuk melakukan penelitian yang berkaitan dengan peran wali murid terhadap kedisiplinan siswa. Oleh karena itu, penulis menuliskannya dalam bentuk skripsi yang berjudul "peran wali murid terhadap pembentukan kedisiplinan siswa di SD Negeri 10 Banda Aceh".

\section{Tujuan Penelitian}

Adapun yang menjadi tujuan dalam penelitian ini adalah:

1. Untuk mengetahui peran wali murid terhadap pembentukan kedisiplinan pada siswa di SD Negeri 10 Banda Aceh.

2. Untuk mendeskripsikan kendala yang dihadapi wali murid dalam pembentukan kedisiplinan pada siswa di SD Negeri 10 Banda Aceh.

3. Untuk menggambarkan upaya yang dilakukan oleh wali murid dalam menghadapi kendala pembentukan pembentukan kedisiplinan pada siswa di SD Negeri 10 Banda Aceh.

\section{KAJIAN PUSTAKA}

\section{Peran Wali Murid dalam Pendidikan}

Keluarga adalah merupakan lembaga pendidikan yang utama dan pertama dalam masyarakat karena dalam keluargalah manusia dilahirkan, bekembang menjadi dewasa. Bentuk dan isi serta cara-cara pendidikan di dalam keluarga akan selalu mempengaruhi tumbuh dan berkembangnya watak budi pekerti dan kepribadian setiap manusia.

Adapun peran wali murid menurut William Stainback dan Susan (2005: 22 antara lain:

a. Peran sebagai fasilitator

Orang tua bertanggung jawab menyediakan diri untuk terlibat dalam membantu belajar anak di rumah, mengembangkan keterampilan belajar yang baik, 
memajukan pendidikan dalam keluarga dan menyediakan sarana alat belajar seperti tempat belajar, penerangan yang cukup, buku-buku pelajaran dan alat-alat tulis.

b. Peran sebagai motivator

Orang tua akan memberikan motivsi kepada anak dengan cara meningkatkan motivasi dalam mengerjakan tugas rumah, mempersiapkan anak untuk menghadapi ulangan, mengendalikan stres yang berkaitan dengan sekolah, mendorong anak untuk terlibat dalam kegiatan-kegiatan sekoalah dan memberi penghargaan terhadap prestasi belajar anak dengan memberi hadiah maupun katakata pujian.

c. Peran sebagai pembimbing atau pengajar

Orang tua akan memberikan pertolongan kepada anak dengan siap membantu belajar melalui pemberian penjelasan pada bagian yang sulit dimengerti oleh anak, membantu anak mengatur waktu belajar, dan mengatasi masalah belajar dan tingkah laku anak yang kurang baik.

\section{Pengertian Kedisiplinan}

Menurut Kusnianto (2009:39) disiplin adalah suatu kondisi yang tercipta dan terbentuk melalui proses dari serangkaian perilaku yang menunjukkan nilai-nilai ketaatan, kepatuhan, kesetiaan, keteraturan dan ketertiban. Disiplin akan membuat seseorang tahu dan dapat membedakan hal-hal apa yang seharusnya dilakukan, yang wajib dilakukan, yang boleh dilakukan, yang tak sepatutnya dilakukan karena merupakan hal-hal yang dilarang. Disiplin pada hakikatnya akan tumbuh dan terpancar dari hasil kesadaran manusia. Sebaliknya, disiplin yang tidak bersumber dari kesadaran hati nurani akan menghasilkan disiplin yang lemah dan tidak akan bertahan lama. Disiplin belajar adalah hal yang sangatlah diperlukan bagi setiap siswa, dengan adanya disiplin belajar, tujuan pendidikan akan lebih mudah tercapai (Sanjaya, 2005:9).

\section{METODE PENELITIAN}

\section{Tempat dan Waktu Penelitian}

Tempat penelitian tindakan kelas ini dilakukan di SD Negeri 10 Banda Aceh. Sekolah ini berada di Gampong Panteriek Banda Aceh. Penelitian ini dilaksanakan pada tanggal 24 Oktober 2016.

\section{Subjek Penelitian}

Populasi merupakan keseluruhan subjek yang akan diteliti, yaitu seluruh siswa yang terdapat di SD Negeri 10 Banda Aceh yang berjumlah 300 orang. Sampel dalam penelitian ini berjumlah 30 orang wali murid dan 30 orang siswa dalam penyebaran angket untuk melihat peran wali murid dalam pembentukan kedisiplinan.

\section{Teknik Pengumpulan Data}

Tehnik pengumpulan data dalam penelitian ini menggunakan wawancara dan angket.

\section{Teknik Analisis Data}

Penelitian ini menggunakan rumus sederhana untuk menganalisis angket. Adapun rumus yang digunakan sebagai berikut:

$$
P=\frac{F}{N} x 100 \% \text { (Sudijono, 2006: 40) }
$$

Keterangan : 


$$
\begin{aligned}
& \mathrm{P} \quad=\text { Persentase } \\
& \mathrm{F} \quad=\text { Frekuensi } \\
& \mathrm{N} \quad \text { : Jumlah Sampel } \\
& \text { 100\%: Bilangan konstanta (tetap) }
\end{aligned}
$$

\section{HASIL PENELITIAN DAN PEMBAHASAN Hasil Penelitian}

Hasil penelitian ini terbagi atas dua bagian, yaitu hasil penelitian dari penyebaran angket dan wawancara. Peneliti menyebarkan angket dan melakukan wawancara untuk mendapatkan informasi yang lebih rinci mengenai informasi yang belum didapatkan dari jawaban yang terdapat pada angket.Peneliti menjabarkan hasil penelitian tersebut sebagai berikut:

\section{Hasil Analisis Peran Wali Murid Terhadap Pembentukan Kedisiplinan Siswa di SD Negeri 10 Banda Aceh berdasarkan Data dari Wali Murid}

Pengumpulan data dilakukan melalui pemberian angket mengenai peran wali murid terhadap pembentukan kedisiplinan siswa di SD Negeri 10 Banda Aceh.Peneliti memberikan angket kepada 30 orang wali murid di sekolah tersebut. Peneliti meminta kesedian parawali murid untuk mengisi angket tersebut. Berikut ini merupakan penjabaran dari jawaban yang diberikan oleh parawali murid.

\section{Hasil Analisis Wawancara}

Peneliti melakukan wawancara dengan tiga orang komite sekolah berkaitan dengan peran wali murid dalam pembentukan kedisiplinan pada anak. Disiplin diri sangat diperlukan di era globalisasi oleh subyek didik agar mereka mampu memberikan wahana dalam perubahan dunia yang serta mega cepat sehingga tidak terbawa oleh arus perubahan. Tidak disiplin mendorong terjadinya percecokan, pertengkaran, perkelahian, pembunuhan secara sadis diantara sesama hamba Tuhan, dan hanyut dalam perubahan. Disiplin diri penting ditanamkan sedini mungkin pada diri anak. Hasil penelitian menunjukkan bahwa wali murid melakukan pembinaan kedisiplinan terhadap anak.

Hasil wawancara yang dilakukan dengan komite sekolah (ES) menunjukkan bahwa orang tua mengarahkan anak dalam belajar di rumah dan menyelesaikan tugastugas (PR) di sekolah. Oleh karena itu, orang tua melakukan berbagai langkah dan upaya untuk meningkatkan kedisiplinan siswa, diantaranya mengarahkan anak dalam mengatur jadwal bermain dan belajar. Membantu anak menyelesaikan tugas yang sulit dan mengintakan anak dalam mempersiapkan segala kebutuhan sekolah seperti alat tulis dan pakaian sekolah.

Hasil wawancara juga menunjukkan bahwa komite sekolah lainnya (WT) melakukan berbagai pembinaan agar anak memiliki kedisiplinan. Orang tua juga memberikan contoh dan teladan kepada anak berkaitan dengan kedisiplinan. Orang tua dalam membantu anak mengembangkan disiplin dirinya harus menggunakan sistem pola asuh bina kasih. Sistem ini efektif, karena dimensi kognitif norma moral tersimpan dalam ingatan, sehingga dimensi kognitif tersusun secara komulatif dan terintegrasikan kedalam struktur yang makin komplek, terdiri dari norma,moral yang berkembang pada anak berkenaan dengan bagaimana seharusnya bertindak dan seharusnya tidak bertindak. Orang tua dalam menanamkan disiplin diri pada anak harus mengupayakan anak berdialog dengan anggota keluarga, lingkungan untuk mengembangkan disiplin dirinya 
Hasil wawancara dengan komite sekolah (YU) juga menunjukkan bahwa orang tua memberikan pengawasan terhadap perkembangan pendidikan pada anak. Jika anak tidak mengerjakan tugas atau PR maka orang tua akan memberikan hukuman yang membuat anak tidak mengulangi kesalahannya. Hukuman yang diberikan merupakan hukuman ringan yang bertujuan memberikan efek jera pada anak.

Peneliti juga melakukan wawancara dengan komite sekolah dan mendapatkan informasi bahwa belum semua siswa memiliki kesadaran akan kedisiplinan. Masih terdapat siswa yang tidak menjalankan tata tertib sekolah dengan baik dan sesuai aturan. Akan tetapi, komite sekolah juga menyampaikan bahwa wali murid telah memberikan dukungan dalam pelaksanaan kedisiplinan siswa, seperti mengantarkan anak ke sekolah tepat waktu, ikut terlibat dalam perkembangan pendidikan anak dan berkomunikasi dengan guru untuk mendiskusikan perkembangan pendidikan anak.

\section{Pembahasan}

Disiplin diri pada anak sangatlah membutuhkan peran orang tua. Tanpa peran orang tua anak tidak akan bisa mengembangkan disiplin diri. Anak yang hidup dalam keluarga yang harmonis dapat membantu anak dalam mengembangkan disiplin diri. Wali murid di SD Negeri 10 Banda Aceh berperan aktif dalam pembentukan disiplin pada anak.Keluarga merupakan salah satu lembaga yang mengemban tugas dan tanggung jawab dalam mencapai tujuan pendidikan umum yaitu mengupayakan subjek didik menjadi pribadi yang utuh dan terintegrasi. Maka tugas dan tanggung jawab keluarga (orang tua) adalah menciptakan situasi dan kondisi yang memuat iklim yang dapat dihayati anak-anak untuk memperdalam dan memperluas makna-makna esensial.

Hasil analisis angket dan wawancara menunjukkan bahwa orang tua melakukan berbagai langkah dan upaya untuk meningkatkan kedisiplinan siswa, diantaranya mengarahkan anak dalam mengatur jadwal bermain dan belajar. Membantu anak menyelesaikan tugas yang sulit dan mengintakan anak dalam mempersiapkan segala kebutuhan sekolah seperti alat tulis dan pakaian sekolah. Orang tua juga memberikan contoh dan teladan kepada anak berkaitan dengan kedisiplinan. Orang tua dalam membantu anak mengembangkan disiplin dirinya harus menggunakan sistem pola asuh bina kasih.

Bantuan orang tua dalam meletakkan dasar-dasar dan mengembangkan disiplin diri anak adalah menciptakan situasi dan kondisi yang mendorong anak memiliki dasardasar disiplin diri anak dan dalam pengembangannya melibatkan dua subjek yaitu: (1) orang tua sebagai pendidik, dan (2) anak sebagai si terdidik. Bantuan orang tua kepada anak untuk memiliki dasar-dasar disiplin diri dan mengembangkannya merupakan suatu pekerjaan dari pendidik. Dalam hal ini pendidik dapat mempengaruhi atau memasukkan sesuatu yang bersifat psikologis kepada si terdidik agar mau bekerja sama dalam pencapaian tujuan sehingga akhirnya dapat mengerjakan sendiri.

Analisis wawancara dengan komite sekolah menunjukkan bahwa belum semua siswa memiliki kesadaran akan kedisiplinan. Mash terdapat siswa yang tidak menjalankan tata tertib sekolah dengan baik dan sesuai aturan. Akan tetapi, komite sekolah juga menyampaikan bahwa wali murid telah memberikan dukungan dalam pelaksanaan kedisiplinan siswa, seperti mengantarkan anak ke sekolah tepat waktu, ikut terlibat dalam perkembangan pendidikan anak dan berkomunikasi dengan guru untuk mendiskusikan perkembangan pendidikan anak.

\section{Kesimpulan}


Berdasarkan pembahasan yang telah dilakukan penulis pada bab-bab sebelumnya, maka penulis menyimpulkan yaitu peran wali murid terhadap pembentukan kedisiplinan pada siswa di SD Negeri 10 Banda Aceh, sebagai berikut wali murid menyatakan sangat sering dalam melakukan peranannya sebagai fasilitator dalam pembentukan disiplin anak,demikian juga dalam menjalankan perannya sebagai motivator dan pendidik/ pengajar bagi anaknya. Wali murid menolng anak saat menghadapi kesulitan dalam mengerjakan tugas, menyelesaikan hal-hal yang sulit, mengatur waktu anak dalam belajar, memimbing tingkah laku anak dan mengajarkan pentingnya belajar secara disiplin. Kendala yang dihadapai wali murid dalam pembentukan kedisiplinan pada anak dikarenakan beberapa factor diantaranya keterbatasan waktu yang dimiliki wali murid, khususnya yang bekerja. Selain itu, wali murid juga tidak dapat mengawasi perkembangan pendidikan anak setiap waktu. Upaya yang dilakukan oleh wali murid dalam mengatasi kendala saat pembentukan kedisiplinan siswa adalah dengan memberikan bimbingan terhadap anak secara berkelanjutan sehingga siswa terbiasa menerapkan kedisiplinan, wali murid juga memberikan hadiah dan pujian terhadap siswa yang telah mampu menerapkan kedisiplinan.

\section{DAFTAR PUSTAKA}

Kusnianto. 2009. Kedisiplinan. Yogyakarta: Pustaka Belajar

Rahmat. 2008. Pembelajaran Karakter. Jakarta : Rineka Cipta

Sudijono. 2006. Statistika untuk Penelitian, Bandung, Alfabeta

Sunarto dan Hartono. 2008. Perkembangan Peserta Didik. Jakarta : Rineka Cipta

Sanjaya. 2005. Strategi pembelajaran Berorintasi Standar Proses Pendidikan. Jakarta: Kencana Prenada Media

William Stainback dan susan. 2005. Peran wali murid dalam pendidikan. Yogyakarta: Andi Offset 